\title{
Significance of rubella virus infection in juvenile chronic polyarthritis
} THOMAS J. SCHNITZER, BARBARA M. ANSELL, GEORGE T. HAWKINS, AN $\frac{\mathbb{0}}{\omega}$
WILLIAM C. MARSHALL

From the MRC Rheumatism Unit, Canadian Red Cross Memorial Hospital, Taplow, Maidenhead, Berks. and the Institute of Child Health, University of London

SUMMARY Fifty-three patients under the age of 5 years with definite juvenile chronic polyarthrit (JCP) were examined for serological evidence of rubella infection. The prevalence of rubella antibodf was found to be low and did not differ significantly from that found in normal children of simil age. Patients with JCP and antibody to rubella virus had a clinical course indistinguishable from those with no detectable rubella antibody.

The role of viruses in the aetiology and pathogenesis of connective tissue diseases has been widely discussed (Phillips, 1971; Marmion, 1974; Denman, 1975) but definitive data to confirm such a relationship are lacking. Rubella virus has often been proposed to be of aetiological significance, particularly in juvenile chronic polyarthritis (JCP). Seroepidemiological data (Ogra and Herd, 1972; Deinhard et al., 1974; Ogra et al., 1975) and the finding of both a heightened and prolonged antibody response to rubella infection in patients with JCP (Ogra et al., 1975) has recently provided more direct evidence for a possible role of rubella virus in JCP.

An outbreak of rubella which occurred among our hospitalized patients with JCP presented the opportunity to examine the manner in which these patients responded to naturally acquired infection by this agent. The results of that investigation (Howard et al., 1975), while confirming the heightened serological response noted by some (Ogra and Herd, 1972; Ogra et al., 1975) but not all investigators in patients with JCP, stimulated the present study to determine the importance of rubella virus in the aetiology and pathogenesis of JCP. If rubella were an important aetiological agent in a substantial number of children with JCP, a higher incidence of rubella antibody among children with JCP might be expected to be found compared to the normal population. Any

Accepted for publication January 28, 1977

Correspondence to Dr. B. M. Ansell, Division of Rheumatology, Clinical Research Centre, Watford Road, Harrow, Middlesex HA1 3UJ difference between these populations in frequency of antibody to rubella would best be appreciated by studying the youngest age groups as children acquire rubella infection in an age-dependent manner are thus antibody to rubella virus is infrequently foun under the age of 5 years (Dudgeon et al., 1973).

\section{Patients and methods}

Between January 1970 and December 1975, children under the age of 5 years were referred to the MRC Rheumatism Unit at Taplow with definite JCP (Ansell and Bywaters, 1962). Of these, 53 has a serum sample taken before their fifth birthda which was available for study. No difference in ty or age of onset, sex, or subsequent course was founc between those patients studied and the 15 childre for whom a serum sample was not available. The control population consisted of children attendim an outpatient clinic from whom blood samples we being collected for other purposes. None of these children had manifestations of congenital rubella. N

Antibody to rubella virus was detected by means of the haemagglutinin-inhibiting (HI) antibody test as has been previously described (Marshall et at 1971). Sera with HI titres of $1: 8$ or greater were considered positive. Complement-fixing antibody tests were performed in microtitre plates using modification of the method described by Bradstreet and Taylor (1962). Antigens for the complement fixation tests were kindly supplied by Dr. P. BraPstreet, Standards Laboratory, Central Public Heal Laboratory, Colindale. 


\section{Results}

The prevalence of rubella $\mathrm{HI}$ antibody among the 53 patients with JCP is shown in the Table. The prevalence was low in all age groups. The percentage of children up to the age of 4 with rubella antibody closely paralleled the data for the control population. A diminished prevalence of rubella antibody was noted in the oldest JCP age group sampled (4-5 years); this difference is not significant $(P>0 \cdot 20)$ and may be due to the limited sample size. The titres of $\mathrm{HI}$ antibody in the 6 children who were seropositive ranged from $1: 16$ to $1: 256$ (geometric mean titre $45 \cdot 3)$.

Table Prevalence of rubella HI antibody in JCP and control children

\begin{tabular}{lllll}
\hline Children & Age $(y r)$ & & & \\
\cline { 2 - 5 } & $I$ & 2 & 3 & 4 \\
\hline JCP & $0 / 2$ & $1 / 9$ & $3 / 20$ & $2 / 22$ \\
\multirow{2}{*}{ Control } & $(0 \%)$ & $(11 \%)$ & $(15 \%)$ & $(9 \%)$ \\
& $2 / 73$ & $5 / 81$ & $10 / 78$ & $11 / 57$ \\
& $(2.7 \%)$ & $(6.1 \%)$ & $(13 \%)$ & $(19 \%)$ \\
\hline
\end{tabular}

Comparison of the $6 \mathrm{JCP}$ children with rubella antibody to the remaining 47 children failed to show any differences in age or type of onset of JCP, sex, number of joints involved, presence of autoantibodies to DNA or smooth muscle, history of prior vaccination (DPT, vaccinia, polio, rubella), or clinical history of childhood diseases, including rubella. The subsequent course of the disease, during follow-up ranging from 6 months to $6 \frac{1}{2}$ years, likewise appeared to be no different in the two groups.

Other serological data obtained in the entire group of patients showed complement-fixing antibodies to adenovirus ( $61 \%$ of patients), herpes simplex ( $40 \%)$, influenza $A$ and $B$ ( $26 \%$ and $28 \%$ respectively), measles $(57 \%)$, mumps $(59 \%)$, and mycoplasma pneumonia $(53 \%)$.

\section{Discussion}

As the great majority of young patients with definite JCP have been shown to have no serological evidence of rubella infection, it seems unlikely that this agent is of aetiological significance in JCP. Any further theories attempting to implicate rubella in the aetiology of JCP, to be consistent with these findings, would have to invoke a specific immunological hyporesponsiveness to primary rubella infection in almost all children destined to develop JCP. The fact that patients with JCP who do not have detectable antibody to rubella can be infected in a normal fashion by this virus (Ogra et al., 1975; Linnemann et al., 1975) and that their serological response occurs with an antibody pattern typical of a primary rather than a secondary response (Linnemann et al., 1975; Al-Nakib et al., 1975; Pattison, 1975) makes the existence of such an immunological abnormality unlikely.

The high incidence reported by Ogra et al. (1975) of rubella antigen present in synovial cells of patients with JCP and the general findings of heightened IgG and persistent levels of IgM rubella antibody in patients with JCP (Ogra et al., 1975) raise the possibility that rubella infection of patients with pre-existing JCP may commonly result in persistence of this viral agent. Cartilage (Smith et al., 1973) and synovial tissue (Parker et al., 1972) have both been shown to be capable of supporting multiplication of rubella virus. If these tissues manifest increased susceptibility to persistent or chronic rubella infection as a consequence of involvement by the pathological process of JCP, an explanation would be provided for both the heightened antibody response, comparable to that of patients with proven rubella arthritis (Ogra et al., 1975), and the finding of rubella antigen in cells from the joints of patients with JCP.

This hypothesis, while supported by indirect evidence including the demonstration of a relationship between the extent of joint involvement and the magnitude of the rubella antibody titre (Cassidy et al., 1974) and the finding of normal rather than raised rubella antibody titres in patients who develop JCP later in life after acquiring rubella infection (Lerman et al., 1971), is also amenable to direct testing. It would be expected that rubella virus, as well as rubella antigen, should be detectable in the joints of patients with JCP at the time they develop clinical rubella infection. A systematic examination for the presence of rubella virus in the joints of such patients has not yet been made, and in the single case reported (Ogra and Herd, 1971) the presence of neutralizing antibody may have prevented recovery of the virus. However, as patients with JCP undoubtedly either acquire natural rubella or will be vaccinated with live rubella virus, it should be feasible to determine whether joint infection and viral persistence are common accompaniments of rubella infection in this population.

Rahal et al. (1976) have recently presented data supporting a causal relationship between preceding common viral infections and the development of nonspecific febrile arthritis. They have also suggested that in some instances such infections might be related to the development of juvenile rheumatoid arthritis. However, the serological data in this group of JCP patients failed to show evidence of a strikingly 
high incidence of previous infection with other common viral agents.

We thank Ella Stephenson for her unflagging aid in obtaining the necessary clinical material without which this work would not have been possible.

\section{References}

Al-Nakib, W., Best, J. M., and Banatvala, J. E. (1975). Rubella-specific serum and naso-pharyngeal immunoglobulin responses following naturally acquired and vaccine-induced infection. Lancet, 1, 182-185.

Ansell, B. M., and Bywaters, E. G. L. (1962). Diagnosis of 'probable' Still's disease and its outcome. Annals of the Rheumatic Diseases, 21, 253-262.

Bradstreet, C. M. P., and Taylor, C. E. D. (1962). Technique of complement fixation test applicable to the diagnosis of virus diseases. Monthly Bulletin of the Ministry of Health, 21, 96-104.

Cassidy, J. T., Shillis, J. L., Brandon, F. B., Sullivan, D. B., and Brockett, R. G. (1974). Viral antibody titres to rubella and rubeola in juvenile rheumatoid arthritis. Pediatrics, 54, 239-244.

Deinard, A. S., Bilka, P. J., Venters, H. D., Herrmann, K. L., and Page, A. R. (1974). Rubella antibody titres in rheumatoid arthritis. Lancet, 1, 526-528.

Denman, A. M. (1975). The viral theory of connective tissue diseases: a review. Medical Biology, 53, 61-84.

Dudgeon, J. A., Peckham, C. S., Marshall, W. C., Smithells, R. W., and Sheppard, S. (1973). National congenital rubella surveillance program. Health Trends, 5, 75-79.

Howard, A., Ansell, B. M., and Powell, R. (1975). Immunoglobin levels during rubella in children suffering from Still's disease. (Abst.) Annals of the Rheumatic Diseases, 34, 204.

Lerman, S. J., Nankervis, G. A., Heggie, A. D., and Gold, E. (1971). Immunologic response, virus excretion and joint reactions with rubella vaccine. Annals of Internal Medicine. 74, 67-73.

Linnemann, C. C., Jr., Levinson, J. E., Burcher, C. R., and Schiff, G. M. (1975). Rubella antibody levels in juvenito rheumatoid arthritis. Annals of the Rheumatic Diseases, 34 354-358.

Marmion, B. P. (1974). A microbiologist's view of invest gative rheumatology. Infection and Immunology in th Rheumatic Diseases, pp. 245-258. Ed. by D. C. Dumonof et al. Blackwell, Oxford.

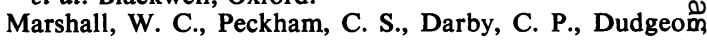
J. A., and Hawkins, G. T. (1971). Further studies with rubella vaccines in adults and chilrden. Practitioner, 20 632-638.

Ogra, P. L., and Herd, J. K. (1971). Arthritis associated wif induced rubella infection. Journal of Immunology, 10 810-813.

Ogra, P. L., and Herd, J. K. (1972). Serologic association ê rubella virus infection and juvenile rheumatoid arthritis? (Abst.) Arthritis and Rheumatism, 15, 121.

Ogra, P. L., Ogra, S. S., Chiba, Y., Dzierba, J. L., ant Herd, J. K. (1975). Rubella virus infection in juvenibe rheumatoid arthritis. Lancet, 1, 1157-1161.

Parker, M. D., McCollum, D. E., and Kerby, G. P. (1972) Susceptibility of cultures of rheumatoid tissues to rubella virus infection. Arthritis and Rheumatism, 15, 275-282.

Pattison, J. R. (1975). Persistence of specific IgM aft natural infections with rubella virus. Lancet, 1, 185-18\%

Phillips, P. E. (1971). Virologic studies in rheumatord arthritis and other connective tissue diseases. Journal ஓ Experimental Medicine, 134, 313s-319s.

Rahal, J. J., Millian, S. J., and Noriega, E. R. (1976). Arthritis associated with induced rubella infection. Journa of the American Medical Association, 235, 2496-2501.

Smith, J., Early, E. M., London, W. T., Fuollo, D. A., an Sever, J. L. (1973). Coxsackie and adenovirus infection. association with acute febrile and juvenile rheumato arthritis. Proceedings of the Society for Experiment Biology, 143, 1037-1041. 